\title{
Financial Performance of Datanotic International
}

\author{
J Pavithra, Gopinathan, Srividhya
}

\begin{abstract}
This undertaking "A Study on the budgetary presentation with reference to Datanotic International" manages the investigation of the liquidity position, benefit of the organization with the assistance of proportion examination. Here the proportion investigation is made to discover the money related execution of the organization. The need of this is task is significant for the organization in settling on a budgetary choice in which suggestions ought to be made. The examination is expected to investigation of the money related execution of the organization in a superior way. It can likewise be required for the administration to apply the related proportions to dissect its liquidity and productivity in a superior way. The extent of this examination is to break down the future proportions its liquidity positions and other monetary instruments. It can likewise be valuable for other association to convey the investigation in the comparative regions. For this investigation optional information, five years asset report of the organization is utilized. The confinements of the investigation are that there is no opportunity to contemplate on the whole execution of the organization and term of the examination is low. That from this investigation the organization's monetary presentation is observed to be great and the organization needs to concentrate on the fluid resources and on the costs of the organization. The principle recommendation that can be given to the organization is that the organization can concentrate on the venture on present moment and long haul to make a decent prospect later on. The organization can likewise make a few benefits over their arrival on the advantage and profit for the venture. [1],[3],[5]
\end{abstract}

The goal of money related investigation is the pinpointing of solidarity and shortcoming of a business undertaking by regrouping and dissecting of figures got from fiscal summary and monetary record by the devices and systems of the board bookkeeping. Money related investigation is as the last advance of bookkeeping that outcome in the introduction of last and the accurate information that helps the business supervisors, banks and financial specialists. [2 ],[ 4],[6]

Money related execution is a significant viewpoint which impacts the long haul dependability, benefit and liquidity of an association. The Evaluation of budgetary execution utilizing Comparative Balance Sheet Analysis, Common Size Balance Sheet Analysis, Trend Analysis and Ratio Analysis had been taken up for the investigation[7],[ 9], [11]

Keywords : financial statement,performance analysis

\section{INTRODUCTION}

\section{A. Financial Statement Analysis}

Revised Manuscript Received on July 22, 2019.

J.Pavithra, Department of MBA, Bharath Institute of Higher Education and Research, Tamilnadu, India. Email: pavithralect@yahoo.com

Gopinathan, Department of MBA, Bharath Institute of Higher Education and Research, Tamilnadu, India. Email: gopinathanmba@ gmail.com

Srividhya, Department of CSE, Bharath Institute of Higher Education and Research, Tamilnadu, India Email: vidhyasrinivasan1890@ gmail.com
Each business concern needs to know the different money related viewpoints for successful basic leadership. The principle point of setting up a fiscal report is to accomplish the goals of the firm in general. The term budget report alludes to a composed gathering of information based on bookkeeping standards and shows to reveal its money related data. $[8],[10],[12]$

\section{B. Nature of Financial Statements}

Fiscal summaries are set up based on business exchanges recorded in the books of Original Entry or Subsidiary books, Ledger and Trial balance. Recording the exchanges in the books of essential section is bolstered by report verifications, for example, vouchers, receipt notes and so forth. [13], [15] , [ 17]

As per the American establishment of affirmed Public Accountants, "Fiscal summary mirrors a blend of recorded actualities, bookkeeping shows and individual decisions; and shows connected influence them tangibly". It is, in this way inferred the nature and precision of the information incorporated into the budget reports are in the fiscal summaries are affected by the accompanying elements: [14],[ 16], [18]

1. Recorded realities concerning the business exchanges.

2. Generally acknowledged bookkeeping standards.

3. Personal decisions.

4. Accounting shows embraced to encourage the bookkeeping system.

\section{Concept Of Finacial Statement}

Fiscal summary likewise called budgetary report, alludes to such articulations as it contains money related data of the endeavor. They are over all universally useful element articulation as the report monetary position and activity aftereffects of an undertaking business at end of record period. Actually, these announcements mirror the aggregate of the synopsis of the books of record. [19],[21],[23]

\section{Financial Performance Analysis}

Financial execution assessment is the path toward recognizing the cash related characteristics and weaknesses of the firm by properly working up the association between the things of advantage report and advantage and setback account. It moreover helps in present minute and whole deal foreseeing and advancement can be identified with the help of cash related execution assessment. 
The word reference essentialness of 'assessment' is to decide or segregate a thing in to its segment or sections parts for following their association with the things as whole and to each other. [20],[22], [24]

The examination of financial report is a system of surveying the association between the fragment bits of spending report to get a predominant appreciation of the firm position's and execution. This examination can be endeavored by the administrators of the firm or by social occasions outside the to be explicit, owners, leasers, monetary masters and others.

\section{E. Meaning of Financial Statement}

A monetary report is an aggregation of data formed by cognizant and unfaltering Accounting systems. Its inspiration is to pass on an understanding of some cash related pieces of a business firm. It may exhibit a circumstance at a moment in time as because of an advantage report, or it may reveal game plan of activities over a given time allotment, as by virtue of a pay clarification. [25],[27],[29]

The declaration revealing status of theories is known as resource report and the declaration exhibiting the result is known as advantage and incident record". Along these lines, the term spending outline has been extensively used to address two enunciations orchestrated by accountants around the completion of unequivocal period. They are: (I) advantage and disaster record or pay declaration; and (ii) Balance sheet or clarification of cash related position. [26],[28],[30]

Monetary synopses are set up as a last result of cash related accounting and are the genuine wellsprings of budgetary information of an endeavor. Spending synopses are furthermore called as cash related reports. [31],[33],[32]

The spending synopses are set up dependent on recorded convictions. The recorded convictions are those which can be imparted in cash related terms. The declarations are set up for a particular period, generally for one year.

\section{OBJECTIVES}

\section{A.PRIMARY OBJECTIVE}

The main aim of the study is to ascertain financial performance of DATANOTIC INTERNATIONAL for the past five years.

\section{B.SECONDARY OBJECTIVE}

- To discover the productivity of the organization utilizing money related proportions like gainfulness proportions, turnover proportion and dissolvability proportion of the organization.

- To discover the liquidity position of the organization.

- To study the exhibition of organization through near examination.
- To give appropriate recommend to improve the budgetary exhibition of the organization.

to improve the financial performance of the company

\section{DATA ANALYSIS AND INTERPRETATION}

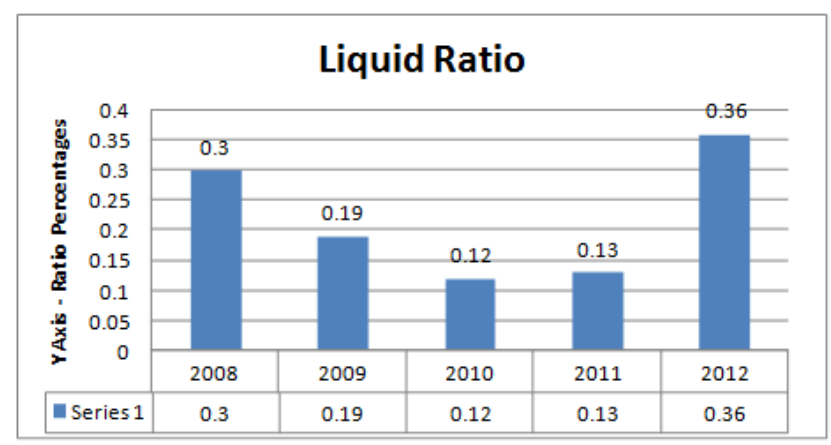

Fig:1 LIQUID RATIO

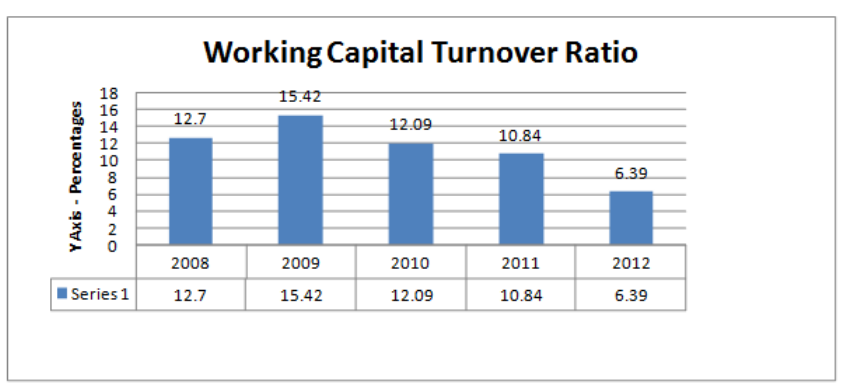

Fig:2 WORKING CAPITAL TURNOVER RATIO

Table:1 Showing Profitability Ratio

\begin{tabular}{|l|l|l|l|}
\hline Year & $\begin{array}{l}\text { Profit after tax } \\
\text { (Rs in crs) }\end{array}$ & $\begin{array}{l}\text { Sales } \\
\text { (Rs in crs) }\end{array}$ & Ratio \\
\hline 2012 & 242 & 12114.44 & 1.99 \\
\hline 2011 & 240 & 12289.54 & 1.95 \\
\hline 2010 & 300 & 12294.56 & 2.44 \\
\hline 2009 & 316 & 11721.79 & 2.69 \\
\hline 2008 & 280 & 11402.16 & 2.45 \\
\hline
\end{tabular}

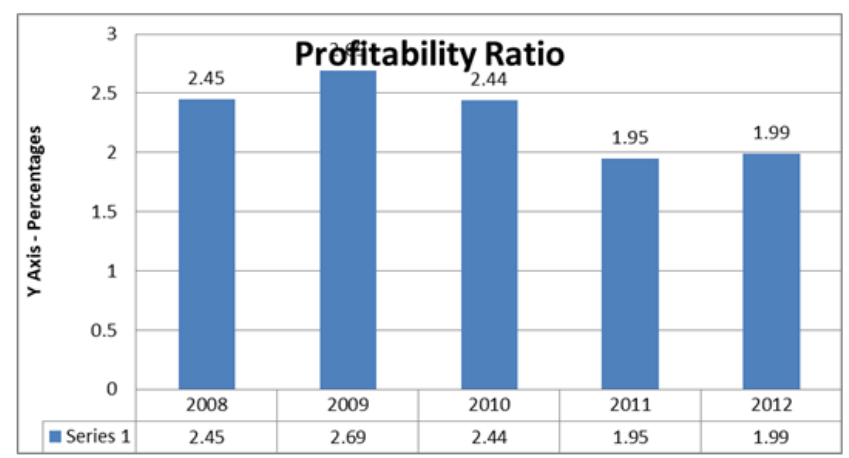

Fig:3 Chart Showing Profitability Ratio 


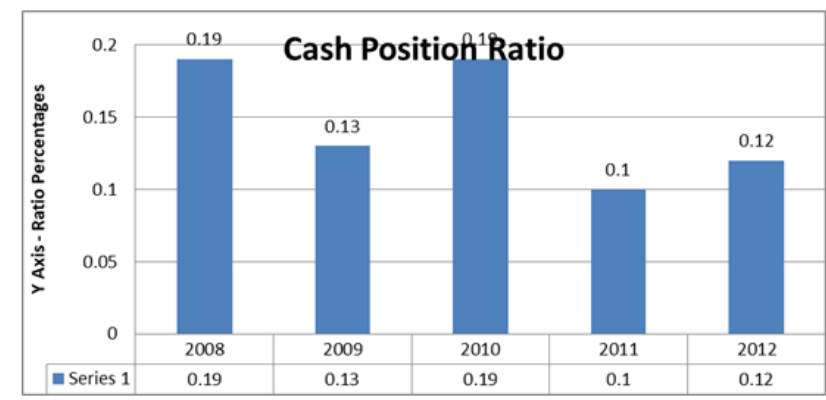

Fig:4 CASH POSITION RATIO

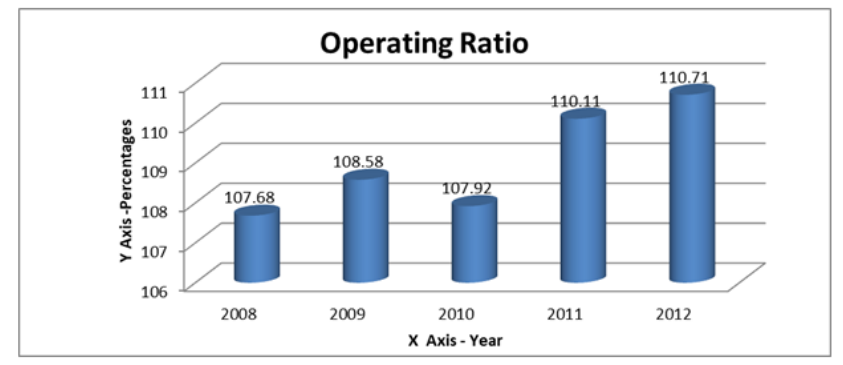

Fig:5 Operating Ratio

Table: 2 Debtors Turnover Ratio

\begin{tabular}{|l|l|l|l|}
\hline Year & $\begin{array}{l}\text { Net worth } \\
\text { (Rs in crs })\end{array}$ & $\begin{array}{l}\text { Total Assets } \\
\text { (Rs in crs })\end{array}$ & Ratio \\
\hline 2012 & 1893 & 4769.09 & 0.39 \\
\hline 2011 & 1122 & 3362.48 & 0.33 \\
\hline 2010 & 1016 & 3089.94 & 0.32 \\
\hline 2009 & 860 & 2583.35 & 0.33 \\
\hline 2008 & 698 & 1935.93 & 0.36 \\
\hline
\end{tabular}

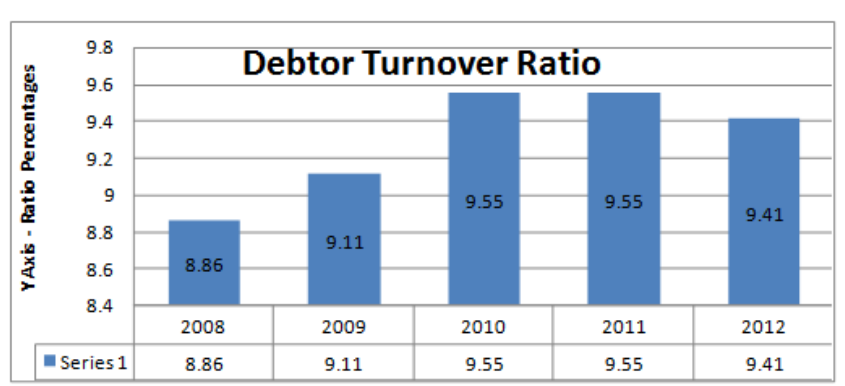

Fig:6 Debtors Turnover Ratio

Table: 3 Proprietary Ratio

\begin{tabular}{|l|l|l|l|}
\hline Year & $\begin{array}{l}\text { Net Sales } \\
\text { (Rs in crs })\end{array}$ & $\begin{array}{l}\text { Average Debtors } \\
\text { (Rs in crs })\end{array}$ & Ratio \\
\hline 2012 & 12114.44 & 1286.45 & 9.41 \\
\hline 2011 & 12289.54 & 1286.45 & 9.55 \\
\hline 2010 & 12294.56 & 1286.45 & 9.55 \\
\hline 2009 & 11721.79 & 1286.45 & 9.11 \\
\hline 2008 & 11402.16 & 1286.45 & 8.86 \\
\hline
\end{tabular}

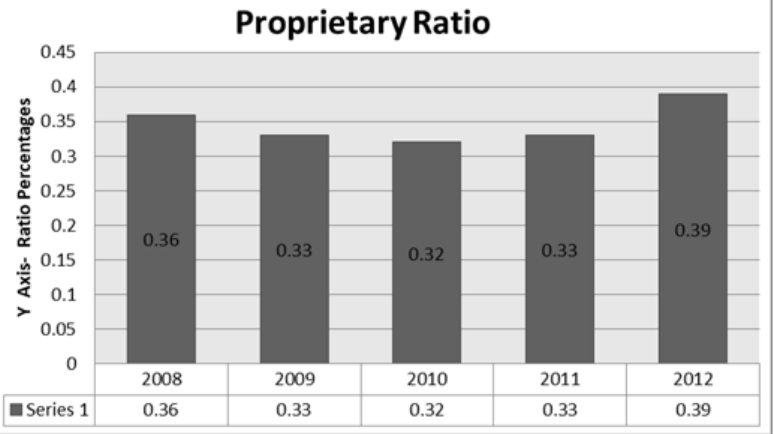

Table: 2 Proprietary Ratio

TABLE: 3 SHOWING COMPARATIVE BALANCE SHEET (2011-2012) (Rs In Crs )

\begin{tabular}{l} 
PARTICULARS \\
\hline LIABILITIES
\end{tabular}

TABLE:4 SHOWING COMMONSIZE BALANCE SHEET - 2008-2009(Rs In Crs )

\begin{tabular}{|c|c|c|c|c|}
\hline PARTICULARS & 2008 & PERCENTAGE & 2009 & PERCENTAGE \\
\hline \multicolumn{5}{|l|}{ LIABILITIES } \\
\hline Equity Funds & 34 & 4.28 & 34 & 3.06 \\
\hline warrant & - & - & - & - \\
\hline Reserves & 664 & 83.73 & 826 & 74.55 \\
\hline Loan Funds & 84 & 10.59 & 236 & 21.30 \\
\hline Deferred & 11 & 1.40 & 12 & 1.09 \\
\hline TOTAL & 793 & 100 & 1108 & 100 \\
\hline \multicolumn{5}{|l|}{ ASSETS } \\
\hline Fixed assets & 98 & 12.36 & 151 & 13.62 \\
\hline Investments & 295 & 37.20 & 272 & 24.54 \\
\hline Deferred & - & - & - & - \\
\hline Net Current Assets & 400 & 50.44 & 685 & 61.84 \\
\hline TOTAL & 793 & 100 & 1108 & 100 \\
\hline
\end{tabular}

TABLE: 5 SHOWING COMMONSIZE BALANCE SHEET - 2010-2011(Rs in crs)

\begin{tabular}{|l|l|l|l|l|}
\hline PARTICULARS & $\mathbf{2 0 0 9}$ & PERCENTAGE & $\mathbf{2 0 1 0}$ & PERCENTAGE \\
\hline LIABILITIES & & & & \\
\hline Equity Funds & 34 & 3.06 & 34 & 2.46 \\
\hline Share warrant & - & - & - & - \\
\hline Reserves and & 826 & 74.55 & 982 & 71.34 \\
\hline Loan Funds Tax & 236 & 21.30 & 354 & 25.70 \\
\hline Deferred & 12 & 1.09 & 7 & 0.50 \\
\hline TOTAL & 1108 & 100 & $\mathbf{1 3 7 7}$ & $\mathbf{1 0 0}$ \\
\hline ASSETS & & & & \\
\hline Fixed assets & 151 & 13.62 & 170 & 12.35 \\
\hline Investments Tax & 272 & 24.54 & 215 & 15.61 \\
\hline Deferred & - & - & - & - \\
\hline Net Current Assets & 685 & 61.84 & 992 & 72.04 \\
\hline TOTAL & 1108 & $\mathbf{1 0 0}$ & $\mathbf{1 3 7 7}$ & $\mathbf{1 0 0}$ \\
\hline
\end{tabular}

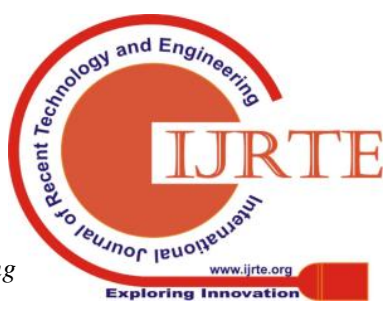




\section{RESULTS}

$>$ The current asset was the increased trend during the year 2010 was 1.57.

$>$ The liquid ratio decreasing year by year that is 0.36 in the year of 2004-05 to 0.30 in the year of 2008 .

$>$ The highest working capital ratio was increased in sales 14.20 in the year of 2009.

$>$ The profitability ratio was always decreased comparing with previous years.

$>$ The cash position ratio shows that the highest cash management in the year 2010 and 2008 was increased to 0.19 .

$>$ The operating ratio in 2008 was 108.20 gradually increased up to 2012 was 111.12 .

$>$ The debtor's turnover ratio was increasing during the year of 2008 to 2010, next two years slowly decreased.

$>$ Proprietary ratio has been increased in the year of 2008 to2012.

$>$ The Gross profit ratio has been increased from the year of 2012 was 9.68

$>$ The Net profit ratio has been increased from the year of 2012 was 8.52

$>$ The Net sales trend percentage increased from the year of 2010 was 104.88 .

$>$ The Net profit trend percentage increased from the year of 2010 was 104.61 .

$>$ The current assets increased the year of 2012 were 3615 .

$>$ The current liabilities constantly increased the year of 2008 to 2012.

$>$ The comparative balance sheet that the loan funds increased $180.95 \%$ to compare $2006 \& 2008$.In the year 2010 \& 2008 increased the loan funds $129.07 \% .2010 \&$ 2008.

$>$ The comparative balance sheet that the investments increased 228.46 to compare

> The comparative balance sheet increased the year 2010 \& 2008 was $78.87 \%$ and decreased the previous year $2009 \& 2010$ was $-2.033 \%$ and increased the year of $2008 \& 2009$ was $24.28 \%$ and increased the year of 2006 \& 2008 was $39.72 \%$.

$>$ The common size balance sheet that Net current assets increased 2010 \& 2008 was 52.18, 2009 \& 2010 was 66.58 and $2008 \& 2009$ was 72.04, $2006 \& 2008$ was 61.84 .

\section{DISCUSSION}

$>$ Company may look into the measures how to reduce the loans and advances in the coming periods.

$>$ Company may look into maintain the current assets and current liabilities. Current liabilities may reduce coming periods.

$>$ It is suggested to the company can strongly focus on cost reduction strategy that will make a company more profitability.

$>$ The company has a bright future if it concentrates more on its working capital short term, investments, thus achieving the overall objectives of the company.

$>$ Thus it is essential to avoid excessive liquidity but to maintain sufficient liquidity to ensure smooth running of the company's operation.
The company has better liquidity position and has to maintain same in the future.

\section{CONCLUSION}

The proficient and smooth working of the considerable number of exercises of the organization relies on the money related execution of the organization. The monetary presentation examination subsequently is a forward-looking activity as it is useful in future money related arranging basic leadership. It decide to examination anticipating future monetary position. Through budget report investigation, the present position and working proficiency of the firm all in all and its various divisions can be distinguished. Further, the explanations behind change in the gainfulness monetary position of the firm can be found and fundamental measures can be taken.

Budgetary execution can improve the monetary quality of organization. The organization's liquidity position needs to increment and it will tackle future issue. The organization is keeping up the stores and surplus better so it can confront budgetary worry later on. To appropriate keep up of budgetary execution to accomplish the organization objective.

\section{REFERENCES}

1. G BharthVajan R., Ramachandran S.,Psychographic dimensions of training,2016,International Journal of Pharmacy and Technology,V-8,I-4,P-23727-23729

2. Balakrishnan P., Bharthvajan R.,A study on human resource planning in hospitals in Chennai City,2014,International Journal of Applied Engineering Research,V-9,I-22,P-7503-7507

3. Priyadarsini P., Bharthvajan R.,Role of emotional intelligence training programme in reducing the stress of the nurses,2014,International Journal of Applied Engineering Research,V-9,I-22,P-7411-7421

4. Kerinab Beenu G., Bharthvajan R.,Empirical analysis on the cosmetic buying behavior of young women in South India,2014,International Journal of Applied Engineering Research,V-9,I-22,P-7361-7366

5. Balakrishnan P., Bharthvajan R.,Whistling in the wind,2014,International Journal of Applied Engineering Research,V-9,I-22,P-7586-7593

6. Krishnan B., Peter M.,Health hazards of Indian Bpo employee-an alarming issue,2014,International Journal of Applied Engineering Research,V-9,I-22,P-7336-7341

7. Kerinab Beenu G.H., Peter M.,Role of insurance in economic development,2014,International Journal of Applied Engineering Research,V-9,I-22,P-7532-7539

8. Balakrishnan P., Peter M., Priyadarsini P.,Efficiency of safety measures for wellbeing of employees in manufacturing industry,2014,International Journal of Applied Engineering Research,V-9,I-22,P-7376-7382

9. Anbarasi M., Praveen Kumar S.,Online sales promotions of herbal products and its effectiveness towards tanisha.com,2019,Indian Journal of Public Health Research and Development,V-10,I-1,P-195-200

10. Anbarasi M., Praveen Kumar S., Various online marketing and promotions strategies to improve the validation towards the organic products in the pharmaceutical sectors,2019,Indian Journal of Public Health Research and Development,V-10,I-1,P-263-269

11. Loganathan R., Praveen Kumar S.,Grievance handling a key factor for solving issues of employees in an organization,2014,International Journal of Applied Engineering Research,V-9,I-22,P-7483-7491

12. Loganathan R., Praveen Kumar S.,Study on preference of private label brands in super and Hypermarkets,2014,International Journal of Applied Engineering Research,V-9,I-22,P-7327-7335

13. Smitha M., Praveen Kumar S.,Understanding stress and its managementamong the nurses in Chennai city,2014,International Journal of Applied Engineering Research,V-9,I-22,P-7560-7565 
14. Kerinab Beenu G.H., Praveen Kumar S.,A study on the investment behavior of Chennai investors in mutual fund schemes,2014,International Journal of Applied Engineering Research,V-9,I-22,P-7520-7525

15. Loganathan R., Praveen Kumar S.,Retention strategies key for organizational productivity,2014,International Journal of Applied Engineering Research,V-9,I-22,P-7443-7447

16. Pavithra J., Ganesan M., Brindha G.,State wise analysis of microfinance sector in India,2016,International Journal of Pharmacy and Technology,V-8,I-4,P-23417-23432

17. Pavithra J., Ganesan M.,A comparative study on microfinance in India and abroad,2016,International Journal of Applied Business and Economic Research,V-14,I-8,P-5471-5476

18. Pavithra J., Ganesan M.,A study on awareness and impact of micro-financial schemes,2016,International Journal of Applied Business and Economic Research,V-14,I-8,P-5449-5460

19. Senthilmurugan P., Pavithra J.,Consumer preference towards organised retailing with reference to Big Bazaar,2014,International Journal of Applied Engineering Research,V-9,I-22,P-7469-7475

20. Senthilmurugan P., Pavithra J.,Implication of social media marketing in growing healthcare industry,2014,International Journal of Applied Engineering Research,V-9,I-22,P-7448-7456

21. Loganathan R., Pavithra J.,Consumer perception towards private label brand over other brands in super markets and hypermarkets,2014,International Journal of Applied Engineering Research,V-9,I-22,P-7355-7360

22. Kerinab Beenu G., Pavithra J.,Tradeâ€"off between liquidity and profitability in logistics industry,2014,International Journal of Applied Engineering Research,V-9,I-22,P-7398-7401

23. Kerinab Beenu G., Pavithra J.,A study on the prospective consumerâ€ $€^{\mathbf{T M}_{\mathbf{S}}}$ perception towards utility cars in Chennai city,2014,International Journal of Applied Engineering Research,V-9,I-22,P-7526-7531

24. Pavithra J., Dilli Babu P., Ambuli T.V.,A study on budgetary control at Maruti Service Masters, Chennai,2014,International Journal of Applied Business and Economic Research,V-12,I-2,P-151-161

25. Pavithra J., Dilli Babu P., Ambuli T.V.,A study on customer satisfaction of retro Garments Pvt Ltd, Chennai,2014,International Journal of Applied Business and Economic Research,V-12,I-2,P-381-391

26. Kerinab Beenu G.H., Pavithra J., Senthilmurugan P.,A study on the influence of promotional activities for TATA ARIA among consumers in Chennai,2014,International Journal of Applied Engineering Research,V-9,I-22,P-7572-7578

27. Vijayaragavan S.P.,An investigative expert that's general FBG sensors,International Journal of Mechanical Engineering and Technology,V-8,I-8,PP-1500-1505,Y-2017

28. Vijayaragavan S.P.,Equalization routing protocol for $\mathrm{Wi}-\mathrm{Fi}$ sensor strategy,International Journal of Mechanical Engineering and Technology,V-8,I-8,PP-1662-1666,Y-2017

29. Karthik B., Kiran Kumar T.V.U., Vijayaragavan P., Bharath Kumaran E.,Design of a digital PLL using 0.35 $\hat{\mathrm{I}}^{1 / 4 \mathrm{~m}}$ CMOS technology,Middle East Journal of Scientific Research,V-18,I-12,PP-1803-1806,Y-2013

30. Kanniga E., Selvaramarathnam K., Sundararajan M.,Kandigital bike operating system,Middle - East Journal of Scientific Research,V

31. Jasmin M., Vigneshwaran T., Beulah Hemalatha S.,Design of power aware on chip embedded memory based FSM encoding in FPGA,International Journal of Applied Engineering Research,V-10,I-2,PP-4487-4496,Y-2015

32. Jasmin M.,Optimization techniques for low power VLSI circuits,Middle East Journal of Scientific Research,V-20,I-9,PP-1082-1087,Y-2014

33. Jasmin M., Vigneswaran T.,Fuzzy controller for error control of on - Chip communication,2017 International Conference on Algorithms, Methodology, Models and Applications in Emerging Technologies, ICAMMAET 2017,V-2017-January,I-,PP-1-5,Y-2017

\section{AUTHORS PROFILE}

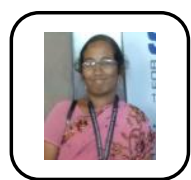

J.Pavithra Assistant Professor, Department of MBA Bharath Institute of Higher Education and Research, Tamilnadu, India

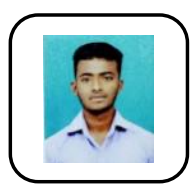

Gopinathan ,Student ,Department of MBA, Bharath Institute of Higher Education and Research, Tamilnadu, India

Srividhya Assistant Professor, Department of CSE, Bharath Institute of Higher Education and Research, Tamilnadu, India 